\title{
AJRC
}

Australia - Japan Research Centre

\section{RAILROAD EXPANSION AND ENTREPRENEURSHIP: EVIDENCE FROM MEIJI JAPAN*⿻}

\section{AJRC Working Papers 02/ 2013 April 2013}

\section{John Tang}

Research School of Economics

Australian National University

\section{Abstract}

Railroads in Meiji Japan are credited with facilitating factor mobility as well as access to human and financial capital, but the impact on firms is unclear. Using a newly developed firm-level dataset and a difference-in-differences model that exploits the temporal and spatial variation of railroad expansion, I assess the relationship between railways and firm activity across Japan. Results indicate that railroad expansion corresponded with increased firm activity, particularly in manufacturing, although this effect is mitigated in less populous regions. These findings are consistent with industrial agglomeration in areas with larger markets and earlier development among both new and existing establishments. 
*The author thanks Tim Hatton, Jeff Williamson, and Ann Carlos as well as seminar participants at the Universitat de Barcelona, University of Oxford, the London School of Economics, the University of Otago, and the University of New South Wales and participants at the Asian Historical Economics Conference for useful comments. This research is supported by grants provided by the ANU College of Business and Economics and the Australian Research Council.

œThis paper was selected as the winner of the Australia-Japan Research Centre's 2012 Crawford Award.

\section{Keywords}

agglomeration; entrepreneurship; firm genealogy; late development

\section{JEL Classification}

L26; N75; O53

\section{Suggested Citation:}

Tang, J. 2013. Railroad expansion and entrepreneurship: evidence from Meiji Japan, AJRC Working Paper No. 2, April 2013. Australia-Japan Research Centre, Crawford School of Public Policy, The Australian National University.

\section{Address for correspondence:}

(E) ajrc@anu.edu.au

ISSN 07288409

ISBN 978-0-86413-3535-7

The Australia-Japan Research Centre (AJRC) conducts research to explore and improve understanding of the economies and economic policy processes in Australia and Japan and both countries' strategic interests in the Asia Pacific economy.

The AJRC Working Paper Series aims to provide a forum for the exchange of topical research and contains the latest research and analysis on the Japanese economy, as well as the political economy, regional integration and trade. The views expressed in AJRC Working Papers are those of the individual authors and do not represent the views of the Australia-Japan Research Centre, the Crawford School, or the institutions to which authors are attached.

The Crawford School of Public Policy is the Australian National University's public policy school, serving and influencing Australia, Asia and the Pacific through advanced policy research, graduate and executive education, and policy impact. 


\section{Introduction}

One of the foreign inventions Commodore Matthew Perry brought with him on his visit to Japan in 1854 was a miniature steam locomotive that ran on a milecircumference track. ${ }^{1}$ Curious onlookers were impressed not only by the novelty of the design, but especially with its speed: one impromptu rider sitting atop the train "clung with a desperate hold to the edge of the roof... and described the experience as though it were flying."'2 Eighteen years and a revolution later, the Meiji emperor opened the country's first railway between Tokyo and Yokohama, which cut the day-long journey by foot to less than an hour by train. ${ }^{3}$

Among the many technological and institutional changes sweeping Japan in the late nineteenth century, the railroad has been credited with playing a leading role in promoting industrialisation and economic growth ${ }^{4}$. This premise is consistent with the benefits of improved transportation infrastructure, which include lower transit costs, market integration and expansion, and intersectoral linkages. ${ }^{5}$ Casual observation of Japan's economic performance seems to corroborate this view: between 1872, when the country's first railway was completed, and 1907, when the government nationalised the industry, national income tripled in real terms. ${ }^{6}$ During this same period, the domestic rail network expanded from 29 to 7,152 kilometres; the number of locomotives from 10 to 1,924; and annual passengers carried from 495,000 to 101 million. $^{7}$

Correlation, however, is not causation, and studies ascribing a causal link between railroads and economic development have typically relied on counterfactual comparisons of social savings or indirect measures of economic activity like population

\footnotetext{
1 This was not the first train seen in Japan; the previous year a Russian envoy demonstrated locomotive technology aboard his ship, but the model was smaller in scale and viewed by many fewer (Free, 2008, p. 22).

2 Ericson (1996), p. 4. This is echoed in contemporary newspaper accounts, which stated that "' $[t]$ he railway train will be as fast as the wind or a cloud. Without such a miraculous device it would be impossible for a human being to do a thing like this unless he possessed the wings of a bird"; in Nagao (1929), p. 5, quoting from the 6 September 1872 issue of Nichi Nichi Shimbun.

3 Free (2008), pp. 11 and 85.

${ }^{4}$ Lockwood (1954) writes that unlike western countries, railroads allowed Japan to "[gain] the economies of a national system almost at the outset" and that they "facilitated a geographic extension of the internal and external market by lowering the cost of moving goods and people" (p. 106). See also Crawcour (1997), pp. 58-61, and Ericson (1996), pp. 31-32 and 52.

${ }^{5}$ Rostow (1960), chapter 4.

6 Data from Maddison (2003). Official Japanese data provide nominal income series starting in 1875, which indicate a six-fold increase by 1907; see Japan Statistical Association (2007), series 13-3, Yamada estimates.

${ }^{7}$ Ibid., series 8-4, 8-6, and 8-14. Historical data begin in 1886 for freight traffic, which grew from 426,000 tons to $18,605,000$ in 1907 (series 8-15).
} 
growth. ${ }^{8}$ Less clear are how the arrival of the railway directly affects entrepreneurs and industries or how these would have behaved differently in the absence of locomotive technology, especially for countries that may have well-developed shipping transport links like Japan. This uncertainty is in part due to a lack of historic firm-level data as well as difficulty in finding appropriate analogues with which to compare economic outcomes.

Another factor to consider is that railroad access may have differential consequences on the connected locations themselves. While railroads may increase economic activity for the macroeconomy, economic geography suggests that agglomeration forces can draw business activity away from newly accessible areas (aka, periphery) toward already established manufacturing centres, and thus mitigate potential economic gains in the former. ${ }^{9}$ This theoretical prediction would seem to apply to Meiji Japan, where there were already large disparities in population and commerce between major cities like Tokyo and Osaka and the more remote prefectures. Taking account of differences between regions may clarify the distributional effects of the railroad and other spatially oriented technologies at a country's early stage in development. 10

The aims of this paper are twofold: to examine the railroad-growth relationship through the lens of firm activity; and to highlight the variable effects of railway access across industries and regions. The research design uses a newly developed firm-level dataset drawn from corporate genealogies and a difference-in-differences methodology that exploits the variation in the timing of railroad network expansion across Japanese prefectures. The genealogies comprise one of the oldest sources of Japanese establishment data across the industrial spectrum, thus providing a more representative view of microeconomic activity than that based on government records and case studies of major firms. ${ }^{11}$ The empirical analysis compares firm activity in

\footnotetext{
8 Classic studies include Fogel (1964) and Fishlow (1965), while Atack et al (2009) and Herranz-Loncan (2011) are more recent examples.

${ }^{9}$ Krugman (1991a). Using Spanish industrialisation as an example, Krugman (1991b) writes that depending on how much transport costs decrease, "over some range closer integration actually leads production to move perversely from the point of view of comparative cost" and he concludes that "railroads and steamships led to deindustrialization of the periphery" (pp. 97-98). This point has been refined more recently with the distinction of original (climate) and acquired (resource investment) features specific to locations; see Crafts and Wolf (2012).

10 Present-day examples may include the expansion of high-speed rail and rollout of broadband internet access; see Crafts (2004).

11 See Tang (2011) for an empirical analysis of technological leadership using firm genealogical data.
} 
regions before and after they gained railroad access while controlling for regions that did not experience a change to their transport technology. Furthermore, by including prefectural population as a measure of market size, one can separate the general effects of railroad expansion on firm activity from those due to agglomeration and provide a simple test of the theoretical predictions from economic geography.

Results indicate that railway access had a small, but positive impact on entrepreneurship across prefectures in general. Furthermore, firm activity differed between industries following the arrival of the railroad, with manufacturing enterprises (in particular, textiles) increasing more rapidly as well as shifting towards more populated locations. This finding is consistent with the rationalisation of capitalintensive production away from smaller markets given greater labour availability and lower transport costs. The documented role of low-value manufacturing to early Japanese industrialisation suggests that this discrete change in firm activity represents a substantive contribution of railroads to economic growth despite an uneven distribution of activity. Discussion of these findings and a number of caveats to interpreting them follows in the final section of the paper.

\section{Background and motivation}

Railroad construction in Japan began with the 29 kilometre stretch between Tokyo and its nearest deep sea port Yokohama. Two years later, in 1874, a similar length of track was laid between Osaka and the port city Kobe, approximately 500 kilometres to the west. While the government, which provided funding for these projects, anticipated that the two major cities of Tokyo and Osaka would be connected by rail in the near future, it was not until 1889 that the Tokaido route between them was finally completed. ${ }^{12}$

The delay was chiefly the result of financing difficulties. Given the costs of its modernisation program, the deteriorating balance of payments, pacifying restless samurai, and controlling inflation, the central government found it difficult to continue investing in railroad infrastructure. ${ }^{13}$ It was not until the 1880 s that network expansion

\footnotetext{
12 The Tokaido route was one of five major routes pre-dating the Meiji Period that were extensively used for long distance travel between the administrative (Tokyo) and commercial (Osaka) centres and outlying regions.

${ }^{13}$ Crawcour (1997), p. 59, and Aoki et al (2000), p. 11. See also Free (2008), chapter 6, and Ericson (1996), chapter 2, for greater discussion of the political and economic context of Meiji railway financing.
} 
began apace, during which the government allowed the private sector to enter the industry and lay its own tracks in local areas and other parts of the country not served by the public network, as shown in Table 1. Both public and private railroads expanded methodically, radiating away from Tokyo and Osaka toward the extremities of the main island of Honshu and connecting major cities in other prefectures, as shown in Figure 1. Short tracks were also laid on the islands of Hokkaido, Shikoku, and Kyushu, which tended to be privately-owned and resource extraction oriented. ${ }^{14}$

\section{[Table 1 and Figure 1]}

The motivations to build a national railway system were legion: for the government, better transport infrastructure meant the centralisation of political authority and national defense, while also spreading economic growth to rural areas. ${ }^{15}$ For the private sector, following fiscal retrenchment in the 1880s and supported by interest rate guarantees, railways were also viewed as a profitable venture. ${ }^{16}$ As railroad investments required larger sums than could be provided by any single private investor, these ventures also made active use of the newly established equity exchanges. To coordinate public objectives with private financing, the government issued a number of laws in the 1880s and 1890s that standardised railway construction as well as identifying which government-planned lines could be bid on by private investors. Localities could also petition for amendments or extensions after 1892, when the Railway Construction Law was passed. Public-private collaboration continued until the nationalisation of major trunk lines between 1906 and 1907, which left only urban tramlines and ancillary extensions in the hands of private investors.

That certain localities and sectors benefitted from railway access is readily documented, such as the silk producing area in central Nagano prefecture. Following

\footnotetext{
${ }^{14}$ Hokkaido and Kyushu were major coal producing regions, which attracted private investment in railway construction linked to the mining industry; Free (2008), pp. 28 and 398-399. Shikoku was relatively resource poor and had minimal railway development except around the two ports of Takamatsu and Tokushima (ibid, p. 28).

${ }^{15}$ Aoki et al (2000), p. 15; Crawcour (1997), pp. 58-61.

${ }^{16}$ Ibid. These considerations notwithstanding, given the existence of coastal and riverine shipping, mountainous terrain, and a system of roads connecting the central cities to outer regions, it is possible that the spread of railroads did not represent a fundamental improvement in transportation access. Since the Tokugawa Period (1603-1868), rice and fish-meal fertiliser were shipped from the northern regions and Hokkaido to central Honshu; Aoki et al (2000), p. 5. Furthermore, hundreds of feudal nobility daimyo paid biennial visits to Tokyo as part of their sankin kotai obligations to the ruling shogunate, which promoted inter-regional transit and commerce.
} 
the completion of the Shin'etsu railroad between northern Nagano and TokyoYokohama in 1893, highly perishable raw silk could be carried to the closest train station 40 kilometres away instead of five times that distance to the capital. When the line was extended to the Suwa district itself, "production...increased dramatically and the cocoon collection area expanded" to cover most of sericultural area in central Japan. ${ }^{17}$ Consumption of coal also grew with the national economy (and was used by the railroad industry itself), which largely relied on railroad or mixed rail-sea transport for distribution. ${ }^{18}$ Countering these examples, however, is the iron and steel sector, which despite obvious industrial linkages to rail construction and transport, arguably did not benefit from them over most of the Meiji Period given the location of deposits and the initial reliance on imported materials. Only following government intervention did railroads contribute to the industry's growth, notably with the 1907 railway nationalisation that guaranteed demand for domestically produced iron and steel. ${ }^{19}$

The industrial and prefectural differences relationship suggest a closer examination of the relationship between Japan's expanding rail system and economic activity. As shown in Figure 2, if one looks at period-wide trend rates of rail network length, national income, exports, and the number enterprises, it is difficult to discern similar patterns between rail expansion and the other indicators, especially given the former's discontinuous growth. ${ }^{20}$

[Figure 2]

Historical studies of Japanese railroads have typically eschewed statistical analysis, however, and few explicitly estimate the railway's impact on the economy. ${ }^{21}$ This may owe to a lack of data from this period; appropriate methods to test hypotheses; or interest in visiting a topic considered already settled. Fortunately, there is an extensive literature available on this subject for other countries, and empirical studies suggest that the railroad usually had a positive effect on economic welfare

\footnotetext{
17 Aoki et al (2000), pp. 21-22, and Ericson (1996), p. 42-48.

18 Ibid.

19 Ibid., pp. 32 and 38.

20 That said, the consequences of railroad construction may not behave in a monotonic or linear fashion. Nonetheless, the trend for manufacturing output is highly similar to that for GDP, and is omitted from the figure for clarity.

21 That said, these works provide a wealth of detail and historical context and are cited throughout this paper.
} 
(although whether the impact is sufficient to drive growth is still debated), as measured through cost savings, consumer surplus, urbanisation, or agglomeration. ${ }^{22}$ Many of these studies, especially those using the social savings approach, rely on counterfactuals to support the claim of welfare gains, which can pose an epistemological problem in identifying causality. ${ }^{23}$

Alternative methods have been used to demonstrate a link between railroads and growth. Donaldson (2010) uses a general equilibrium trade model and highly detailed region price data to estimate the direct impact of an expanding railway system on the colonial Indian economy. His approach allows him to calculate reductions in trade costs and regional price differences as well as gains in income, which he finds amounting to a 16 percent increase due to rail access, much higher than Fogel's estimate of 4.7 percent for the United States in 1890. Atack et al (2009), on the other hand, focus on population growth and urbanisation as possible consequences of railroad development, and find evidence that railroads "caused" urbanisation in the American Midwest. They do so using a novel GIS-augmented dataset and a difference-in-differences empirical model to compare pre- and post-access census years in affected counties against those that remained unaffected in the mid-1800s. In terms of research design, this paper is more similar to the approach taken by Atack et al, with the data and methodology described below.

\section{Research design}

This paper uses a new firm-level dataset collected from corporate genealogies and a difference-in-differences model to identify causality. ${ }^{24}$ The genealogies are based on company histories of 1,089 firms listed on the Tokyo Stock Exchange in 1984 and contain establishment entries dating back to the nineteenth century or earlier. Besides dates of establishment and exit or reorganisation, each entry may also provide the type of ownership, an industry identifier, and the location of establishment. To compare across prefectures and between major industries during the Meiji Period, non Meiji-era

\footnotetext{
${ }^{22}$ A survey of older literature on social savings can be found in O'Brien (1977), while a more recent discussion is Leunig (2010).

${ }^{23}$ Besides a number of assumptions about the elasticity of substitution, actual and opportunity costs, and pricing behavior, the use of a model-based counterfactual as a control group renders long term estimates more difficult to calculate reliably. Externalities and general equilibrium effects are separate and even less tractable issues. 24 Yagura and Ikushima (1986).
} 
start-ups and those without both industry and location are excluded; this decreases the number of establishments to 1,644 . The remaining data cover all 47 prefectures and are disaggregated into four major industry categories: primary production and construction; manufacturing; finance; and other services. The three latter groups can be further classified into thirteen narrower categories, which are shown in Table 2 along with other summary statistics. The sector that had the largest relative change in start-up activity following rail access was non-financial services, followed by manufacturing, while the greatest absolute increase occurred in finance. However, because railroad expansion took place over a few decades, a simple difference between the two periods may be misleading.

[Table 2]

Before proceeding with statistical analysis of the data, it may be useful to assess their validity for use. From the table, it is readily apparent in this dataset that banking by far had the highest number of start-ups over the whole of the Meiji Period, followed by transport and communication, and then textiles. The possible undercount of firms in the primary and non-finance tertiary sectors, which usually predominate in nonindustrial economies, may be due to the composition of the corporate genealogies that they are drawn from (ie., large listed firms), and that both manufacturing and financial firms were better documented historically than those in other sectors, especially in other services. ${ }^{25}$ Many individual genealogies for a given industry do, however, include antecedent firms in different sectors, which reduces the bias from the industrial distribution of firms listed in 1984.

Even with possible representational bias between sectors in the firm sample, for this paper's analysis, a more relevant issue is whether the within industry distribution is consistent over time and location. Unfortunately, there is little documentation of firms at the prefectural level prior to the 1900s for Japan as a whole, much less for individual sectors. Official comprehensive statistics exist for banking at the prefectural level, but only starting in 1893 , when considerable railroad expansion had already

\footnotetext{
${ }^{25}$ Over half (627) of the genealogical collection are manufacturing firms, while financial companies number 131. As of March 2012, there are 1,684 firms listed in the first tier (ie, large capitalisation) of the Tokyo Stock Exchange, of which 823 are classified as manufacturing; see Tokyo Stock Exchange (2012).
} 
taken place. ${ }^{26}$ To compensate for the first 25 years of the Meiji Period which are not covered by official statistics, this paper also uses banking establishment data from the Japanese Bankers Association (JBA) to construct a separate prefectural-level series that dates back to $1868 .^{27}$ These two series, the official statistics and the banking association data, can be used as a baseline reference against which the genealogical data are compared.

[Table 3]

Table 3 provides correlation results of the three banking series across all prefectures using annual bank establishment data. The correlation between the official statistics (GS series) and the banking association (JBA series) is 0.993 at 1 percent statistical significance for the years 1893 to 1912, which indicates virtual equivalence across time and location. For the same period, the GS series has a positive correlation coefficient of 0.828 with the genealogical data (Shuyo series), also at 1 percent significance. Using the entire Meiji Period (1868-1912), the correlation coefficient for the two JBA and Shuyo annual series is 0.875. Breaking down these two series by individual prefecture, the estimates show positive correlations exceeding 0.70 for all 47 prefectures at the 1 percent level, with 41 prefectures having correlations exceeding 0.90.28 As further illustration, Figures 3 and 4 show the share of banks by prefecture from each of the three series in the years 1893 and 1912. The similarity of bank establishment counts among the three series over time and across prefectures indicates reasonable confidence that the genealogical firm data in the banking sector is representative of Japanese banking as a whole. The analysis of the paper in turn assumes similar representativeness for the other sectors.

[Figure 3 and 4 ]

\footnotetext{
26 Japan Ministry of Finance (various).

27 Japanese Bankers Association (2012).

${ }^{28}$ Estimates with Bonferroni and Sidak adjustments do not change the significance levels. The six prefectures with correlation coefficients less than 0.90 are Kumamoto, Miyazaki, Okinawa, Shiga, Tokushima, and Tottori.
} 
The genealogical data are aggregated by year, prefecture, and major industry to create a balanced panel dataset that covers the entire Meiji Period, between 1868 and 1912. They are also combined with railway data from the Ekimei Jiten [Rail Stations in Japan] handbook, published by Chuo Shoin. The handbook provides a comprehensive list of all rail stations established in the country, their founding dates, locations by city and prefecture, and other identifying information. The earliest year of station establishment in each prefecture is used to determine access, and is verified with secondary sources. ${ }^{29}$ Other data come from the Historical Statistics of Japan, published by the Japan Statistical Association, which provide prefecture level data on population and geography. ${ }^{30}$

For the empirical analysis, the paper employs a difference-in-differences methodology, comparing the number of firms established during the Meiji Period in each prefecture before and after it gains access to railroads. ${ }^{31}$ In line with predictions from the economic geography and transaction cost literatures, the rationale is that railroad access is a discrete change that increases factor mobility through lower transportation costs and wider market access, so firm activity would correspondingly increase to take advantage of these improvements. At the same time, it is anticipated that activity would vary based on extant conditions like pre-access market size, leading to agglomeration in larger markets and dispersion in smaller ones. As a point of reference, prefectures that gain access are compared to others that did not experience a contemporaneous change to their railroad infrastructure. The reduced form OLS model follows, with separate regressions for each industry group:

$$
\begin{aligned}
y_{i t}=\beta_{0}+ & \beta_{1} \cdot x_{1 i t}+\beta_{2} \cdot x_{2 i}+\beta_{3} \cdot x_{3 t}+\beta_{4} \cdot x_{4 i t}+\varepsilon_{i t}, \text { where } \\
y_{i t} & =\text { total number of firms for prefecture } i \text { in year } t \\
x_{1 i t} & =\text { rail access dummy variable for prefecture } i \text { in year } t \\
x_{2 i} & =\text { prefecture fixed effect } \\
x_{3 t} & =\text { year fixed effect } \\
x_{4 i t} & =\text { interaction of control variables for prefecture } i \text { in year } t \\
\varepsilon_{i t} & =\text { error term }
\end{aligned}
$$

\footnotetext{
${ }^{29}$ These include Aoki et al (2000), Ericson (1996) and Free (2008).

30 Prefectural population figures for 1884 were collected for the month of January while following years were for December; for consistency, the 1884 data are dated as 1883.

${ }^{31}$ Card and Krueger (1994) is a well-known study using this methodology, and Atack et al (2009) apply it to their study on nineteenth century American railroads. Firms established prior to the Meiji Period are not included in the dataset.
} 
To measure the effect on firm activity, the dependent variable $y_{i t}$ is the total annual number of enterprises in each of the prefectures, indexed by $i$. This number is a net firm count that includes both new Meiji-era start-up establishments in the prefecture and those that continue their operations; those that changed location or discontinued activity are excluded. The main control variable of interest is the term $x_{1 i t}$, which takes the value of zero for all years prior to rail access in prefecture $i$ and the value of one in post-access years. Additional control variables include the prefectural population in 1883, prefectural coastline length, and fixed effects for prefecture and year. Prefectural population can be interpreted as a proxy for local market demand and agglomeration potential and the ordinal ranking among prefectures in 1883 is consistent over the whole period of analysis. One drawback of including this variable is that it reduces the number of years available for analysis, as prefectural population data are unavailable prior to 1883 , whereas eleven prefectures gained access prior to 1884.32 Furthermore, three prefectures gained access after the Meiji Period, and are also excluded from analysis as the genealogical data are collected only up to 1912 . This reduces the number of prefectures available for analysis to 33. Similarly, coastline length is used to proxy for access to coastal transport, which may act as a substitute for rail transport.

For a causal interpretation of estimates based on the difference-in-differences methodology, two conditions should be met. The first is in the choice of control group (ie, prefectures that did not gain railroad access), which must be sufficiently similar to the treatment group in aspects aside from the treatment itself. Since most prefectures gained rail access during the Meiji Period, this suggests that there were no characteristics that predisposed them against rail development. ${ }^{33}$ Moreover, outliers in access timing, such as prefectures that gained access earliest (eg, Tokyo, Osaka) and latest (eg, Okinawa), are also excluded from the analysis for the abovementioned reasons. This allows for division of the prefectures into control and treatment groups based on year of access and other time-invariant features. Table 4 provides the list of prefectures, their dates of railroad access, and other characteristics.

\footnotetext{
32 These prefectures include Tokyo, Kanagawa, Hyogo, Osaka, Kyoto, Hokkaido, Shiga, Fukui, Saitama, Gunma, and Gifu. Note that prefectures which gained access in 1883 are also not included as they would appear to have been treated for the entire period starting that year.

33 This may not have been true for three prefectures that gained railroad access after the Meiji Period: Ehime (1914), Kochi (1924), and Okinawa (2003). These prefectures are also off the main island of Honshu, where most commercial activity took place and government policy was focused.
} 
[Table 4]

This paper uses the year 1893 to separate the prefectures into two groups: a treatment group of 18 prefectures that gained access between 1884 and 1893, and a control group of 15 prefectures that gained access between 1894 and 1912. ${ }^{34}$ This year was selected as it precedes the First Sino-Japanese War (1894-1895), which contributed to a dramatic expansion of the public investment in armaments and public works with possible knock-on effects to firm activity; and it divides the set of prefectures into numerically similar groups. Analysis of these two groups is based on changes in firm activity between 1884 and 1893. These groups are shown on the map of Japan in Figure 5 along with those excluded from analysis.

[Figure 5]

The second condition for a causal interpretation is that the decision to extend the railway network itself is not itself determined by the measured outcome of firm establishment. In other words, entrepreneurs intending to establish firms or maintain operations should not influence the decision to expand rail access to a particular location. This appears to be valid since the government's initial objective to railroad expansion at the start of the Meiji Period was for national security and resource access, not commercial development. 35 Extensions of the railway system north and west in Honshu connected population centres usually along the most geographically and cost efficient paths and were meant to (and did) facilitate troop movements and securing the Pacific coastline. ${ }^{36}$ Moreover, local and commercial lobbying for the placement of railroad track was also not observed prior to the creation of the national parliament in

\footnotetext{
34 The eighteen prefectures in the treatment group include Aichi, Aomori, Ibaraki, Fukuoka, Fukushima, Hiroshima, Iwate, Kagawa, Kumamoto, Mie, Miyagi, Nagano, Nara, Niigata, , Okayama, Saga, Shizuoka, and Tochigi. The fifteen prefectures in the control group include Akita, Chiba, Ishikawa, Kagoshima, Miyazaki, Nagasaki, Oita, Shimane, Tokushima, Tottori, Toyama, Wakayama, Yamagata, Yamaguchi, and Yamanashi. 35 The disinterest in (or ignorance of) commercial viability is highlighted by the lack of cost-revenue analysis made by the government in its early railway ventures and the large cost overruns in the first railroad between Tokyo and Yokohama (Free, 2008, p. 55).

36 This was true even in the late Tokugawa Period, with proposals to build a railroad from Osaka to the then imperial capital Kyoto so as to "speed troops from the Choshu and Satsuma domains in the south [via steamer to Osaka] in the event of an emergency to 'defend' the Emperor from colonizing foreigners" (Free, 2008, p. 29).
} 
1890 and the aforementioned passage of the 1892 Railway Construction law, which presented the government's vision of a national railway system and proposed lines identified for private investment. ${ }^{37}$

To address concerns about control group selection and endogeneity, additional specifications exclude prefectures that have correlation coefficients less than 0.90 in the banking series comparison; those that are landlocked or have long coastlines (over 1,000 kilometres); and those with disproportionately small or large surface areas (outside one standard deviation of the average of prefectures in the control and treatment groups). The first robustness check addresses concerns that the data are not representative of official statistics, while the latter two remove outliers in the availability of coastal transport and ease of railway construction, respectively.

\section{Results}

The main regression results from the difference-in-differences analysis are presented in Tables 5 and 6, the former comparing estimates of firm activity aggregated across all sectors and the latter by major industry group. In Table 5, columns A through $C$ include all prefectures that gained access to railroads between the years 1884 and 1912 , and indicate that rail access is associated with an average prefectural net increase of between 2.19 (column B) and 2.60 (column C) firms per year. ${ }^{38}$ These estimates, however, do not identify rail access as a causal factor and may obtain from a general increase in economic activity and population since all prefectures gained access over the period. When the period of analysis is shortened to create a control group (columns D through F), the net increase in the number of firms following rail access is more modest, from 0.46 (column E) to 0.51 (column F). Nevertheless, given the average number of firms by prefecture without rail access for this period is 3.75 , the lower bound for a net increase in activity due to rail access is approximately 12 percent. In terms of the difference in average firm activity before and after rail access, this represents 23 percent of the total increase.

[Tables 5 and 6]

\footnotetext{
37 "[I]n railroad policy, government bureaucrats essentially had the field to themselves and were able to make decisions independently of private business, which had yet to organize politically or to secure formal representation in the national government" (Ericson, 1996, p. 16). See also Free (2008), p. 21. ${ }^{38}$ This is calculated using the average 1883 prefectural population of 824,149 for prefectures that gained rail access over the period 1884 through 1912. For the years 1884 through 1893, the mean population is 854,448 .
} 
This overall positive effect notwithstanding, when population is interacted with rail access (columns $\mathrm{E}$ and $\mathrm{F}$ ), the individual effect of rail access (row 1 ) is negative and statistically significant while the estimated coefficient on the interaction is positive (row 3). This indicates a decrease in firm activity in prefectures with less than around 700,000 inhabitants in 1883 , which is true for seven of the eighteen prefectures in the treatment group for all years between 1884 and 1893.39 Based on the coefficients in column $\mathrm{F}$ and an average of 1.91 firms per year for these least populated areas, the annual net loss of 0.56 firms represents a 29 percent fall in firm activity. Also of interest is that while its coefficient is consistently negative across specifications, the interaction of rail access and coastline length is never statistically significant, which suggests little impact from the former on firm activity even in areas with greater access to coastal transport.

The results in Table 6 disaggregate firm activity by industry, and show that the change in firm activity is largely due to the manufacturing sector (column B), particularly in textiles (column E). All else equal, manufacturing firm activity in treatment prefectures increased by 0.44 firms, which accounts for 33 percent of firm activity following rail access. In textiles, the increase is 0.27 firms per annum, which is nearly 43 percent of post-rail firm counts.

To consider the impact of rail access on the change in firm numbers instead of the stock of firms, I also use the first difference of annual firm counts as the dependent variable. As shown in Table 7, rail access is only significant when interacted with population in textiles (column E) and to a lesser extent services (column D). This suggests that along with an absolute impact on firm activity shown in previous tables, rail access corresponds to a continuous increase in start-up activity and firm survival (ie, industry expansion) in these sectors.

[Table 7]

To check the robustness of the above estimates, a number of different specifications are used and shown in Tables 8 through 10. The first check limits

\footnotetext{
39 These seven prefectures are Aomori, Kagawa, Iwate, Miyagi, Nara, Saga, and Tochigi, each averaging 610,783 in population over this period.
} 
analysis to prefectures that had correlation coefficients exceeding 0.90 when comparing the genealogical bank series against the Japanese Bankers Association series. Consistent with the earlier estimates, rail access accounts corresponds to an increase in firm activity across all sectors (column A) of 0.45 , which represents 26 percent of the increase between the pre- and post-rail access periods. Again, the effect is concentrated in manufacturing (textiles), which accounts for 56 percent (58 percent) of the increase in total firm activity between periods.

[Table 8]

To improve the correspondence between prefectures in both control and treatment groups, those that were landlocked or had coastlines exceeding 1,000 kilometres are excluded from the estimates reported in Table 9.40 As before, the general effect of rail access is negative and the interaction with population is positive, with the average annual firm count increasing by 0.52 , or 20 percent of the increase between pre- and post-rail periods. Manufacturing and services all experience a net gain in firms following rail access, and for the latter, the interaction with coastline length is positive and slightly statistically significant. More dramatically, for textiles the increase accounts for nearly 73 percent of level change between periods.

[Table 9]

Lastly, given the importance of surface area to railroad construction and timing, I use the subset of prefectures that have surface areas within one standard deviation of the average across control and treatment groups to limit the impact of outliers within the control and treatment groups. The results are qualitatively consistent with earlier results, showing that firm activity rose across all sectors by 1.06 firms per annum, or 44 percent of the level increase between periods. In manufacturing, the increase is 0.68 firms (68 percent), while in textiles it is 0.36 firms (80 percent).

[Table 10]

\footnotetext{
${ }^{40}$ The excluded prefectures are Hiroshima, Kagoshima, Kumamoto, Mie, Nagano, Nagasaki, Nara, Tochigi, Yamaguchi, and Yamanashi.
} 


\section{Conclusion and discussion}

The findings from the difference-in-differences analysis suggest that rail access has a positive impact on firm activity for the economy in general, although there are notable differences between prefectures and industries. Manufacturing, compared to other sectors, experienced substantial increases in firm activity following access after adjusting for initial prefectural population. Furthermore, the opposing signs on rail access and its interaction with population suggests that industrial agglomeration, measured in the number of firms, took place as a response to the railroad and came at the expense of less populated areas.

There are a number of caveats to taking these results at face value, however. The first relates to the dataset, which despite having a larger number of historically undocumented firms than existing sources, may be small to give precise estimates. Since the 1,644 start-up firms in the dataset only include firms that started up during the Meiji Period, the analysis ignores the contribution of firms existing prior to 1868 . Furthermore, more than 900 additional firms were excluded from the analysis as they either had no industry or location identifiers. Considering that the prefectures with the most economic activity, Tokyo and Osaka, were also excluded given their early acquisition of railroads, also diminishes the ability to generalise the results to the economy in absolute measure.

The issue of data selection aside, the findings of increased firm activity, particularly in manufacturing, and of agglomeration are perhaps not obvious given features of the Meiji Japanese economy and existing infrastructure. ${ }^{41}$ While entrepreneurs may have started and continued operations as a result of improved transport links and wider markets, it can be argued that extensive measures of firm activity are not representative of higher capital intensity and within-firm scale expansion. Using firm counts that account for firm entry and exit may not adequately address this concern.

Furthermore, dispersive forces seem as likely to operate since entrepreneurs may not be able to fully capitalize on improved transportation infrastructure for industrial

\footnotetext{
41 That said, research on early twentieth century Japanese factory location suggests that agglomeration took place due to inter-industry linkages and demand for consumption goods; see Imaizumi (2008). These data, however, postdate most of the railway expansion era, so do not directly implicate railroad access itself as a determining factor, although changes in rail freight may have been influential.
} 
production. Contributing factors include private monopolies of regional track and the precedence of passenger over freight traffic, which led to excess demand for freight services. $^{42}$ A consequence of this meant that railways were not obliged to provide discounts for bulk shipping, and thus reduced the incentive to produce more than what was locally demanded, which is one of the qualifications of the Krugman model. ${ }^{43}$ The availability of coastal freight, which was used extensively prior and throughout Japan's industrialisation, may weaken the relevance of newer forms of freight transport, although the above analysis attempts to account for this factor. ${ }^{4}$ Possible complementarity across types of transport can be seen in the revenues earned by private railways, where earnings from passengers exceeded those of freight for every year since 1890 until their nationalisation in 1906-07.45 Thus, a general equilibrium model that accounts for some of these features may provide clearer predictions for this setting.

In terms of economic significance, the difference-in-differences methodology using start-up establishment has the advantages of clear explication and direct measurement of industrial activity. This approach also allows analysis that does not require price and output data, which are difficult to find at the subnational level. Taking the next step of measuring welfare impact, however, is less tractable without more detailed data. While some scholarship directly links entrepreneurship and economic growth, the findings in this paper are only suggestive. ${ }^{46}$ In contrast, studies using the social savings approach incorporate price information can estimate welfare gains for the economy as a whole. If disaggregated price data can be found prior to and following rail access, it may be possible to apply the same difference-on-differences approach but also measure welfare improvement.

\footnotetext{
42 Nagao (1929), pp. 18-19.

43 Free (2008) writes: "[s]uch was the excess demand for railway shipment of goods that when one particular shipper asked for a discount from the [privately-owned] Nippon Tetsudo, the general manager would not allow for any discount at all if the shipper shipped 10,000 tons of freight or 100,000 tons. Freight hauling concerns took second priority to passenger traffic for almost the entire Meiji era" (p. 187). Krugman (1991a) states that a combination of lower transport costs, scale economies, and greater demand for manufacturing would lead to agglomeration. However, even with falling transport costs, it may be that local characteristics still prevail in determining industrial location; see Crafts and Mulatu (2006).

${ }^{44}$ Nagao (1929) writes that the inversion of the passenger-freight revenue ratio compared to other countries "is partly due to the circumstance that Japan, being surrounded by seas, can avail herself more readily of the facilities of maritime transportation" (p. 9). At the same time, rail freight could have positive feedback on sea freight, and thus act as complements instead of substitutes.

45 Japan Statistical Association (2007), series 8-20.

46 See for example Gries and Naudé (2008) and Dejardin (2000).
} 
With these caveats in mind, the empirical results from the current analysis are still suggestive in adding to our understanding about the impact of railways on Meiji Japanese firm activity, and in turn, the country's industrialisation. While the aims of the government and industrialists may not have been necessarily aligned in motivating the expansion of the railroad network, the utility of such infrastructure for both strategic and economic objectives became increasingly obvious, ultimately leading to the nationalisation of the network toward the end of the Meiji Period. 
References

Aoki, Eiichi, Mitsuhide Imashiro, Shinishi Kato, and Yasuo Wakuda (2000). A History of Japanese Railways. Tokyo, Japan: East Japan Railway Culture Foundation.

Atack, Jeremy, Fred Bateman, Michael Haines, and Robert Margo (2009). "Did Railroads Induce or Follow Economic Growth? Urbanization and Population Growth in the American Midwest, 1850-1860." NBER Working Paper Series Number 14640. Cambridge, Massachusetts: National Bureau of Economic Research.

Card, David and Alan B. Krueger (1994). "Minimum Wages and Employment: a Case Study of the Fast-Food Industry in New Jersey and Pennsylvania." American Economic Review 84(4): 772-793.

Chuo Shoin (1995). Ekimei Jiten [Rail Stations in Japan], $5^{\text {th }}$ edition. Japanese language text. Tokyo, Japan: Chuo Shoin Henshubu.

Crafts, Nicholas (2004). "Social Savings as a Measure of the Contribution of a New Technology to Economic Growth." LSE Working Paper 06/04. London, United Kingdom: London School of Economics.

Crafts, Nicholas and Abay Mulatu (2006). "How did the Location of Industry Respond to Falling Transport Costs in Britain before World War I?" Journal of Economic History 66(3): 575-607.

Crafts, Nicholas and Nikolaus Wolf (2012). "The Location of the British Cotton Textiles Industry in 1838: a Quantitative Analysis." Conference paper presented at the 2012 Economic History Society meeting, Oxford, United Kingdom.

Crawcour, E. Sydney (1997). "Industrialization and Technological Change, 1885-1920." The Economic Emergence of Modern Japan. Kozo Yamamura, ed. Cambridge, United Kingdom: Cambridge University Press.

Dejardin, Marcus (2000). "Entrepreneurship and Economic Growth: an Obvious Conjuction?" CREW Working Paper 00-8. Namur, Belgium: University of Namur.

Donaldson, David (2010). "Railroads of the Raj: Estimating the Impact of Transportation Infrastructure." NBER Working Paper Series Number 16487. Cambridge, Massachusetts: National Bureau of Economic Research.

Ericson, Steven (1996). The Sound of the Whistle: Railroads and the State in Meiji Japan. Cambridge, Massachusetts: Council on East Asian Studies, Harvard University Press.

Fishlow, Albert (1965). American Railroads and the Transformation of the Antebellum Economy. Cambridge, Massachusetts: Harvard University Press. 
Fogel, Robert (1964). Railroads and American Economic Growth: Essays in Econometric History. Baltimore, Maryland: Johns Hopkins Press.

Free, Dan (2008). Early Japanese Railways 1853-1914. Tokyo, Japan: Tuttle Publishing.

Gries, Thomas and Wim Naudé (2008). "Entrepreneurship and Regional Economic Growth." UNU-WIDER Research Paper No. 2008/70. Helsinki, Finland: United Nations University World Institute for Development Economics Research.

Herranz-Loncan, Alfonso (2011). "The Role of Railways in Export-Led Growth: the Case of Uruguay, 1870-1913." Economic History of Developing Regions 26(2): 1-33.

Imaizumi, Asuka (2009). "Determinants of Industrial Agglomeration: a Case of Japan, 1900-1935." Conference paper presented at the 2009 World Economic History Congress, Utrecht, the Netherlands.

Japan Ministry of Finance (various). Ginko soran [Comprehensive list of banks], microfilm of annual yearbooks between 1893 and 1912. Tokyo, Japan: Yushodo Publishing.

Japan Statistical Association (2007). Historical Statistics of Japan: New Edition. Tokyo, Japan: Japan Statistical Association.

Japanese Bankers Association (2012). Bank database change history, accessed 1 June 2012. URL: http://www.zenginkyo.or.jp/library/hensen/

Krugman, Paul (1991a). "Increasing Returns and Economic Geography." Journal of Political Economy 99(31): 483-499.

-- (1991b). Geography and Trade. Cambridge, Massachusetts: MIT Press.

Leunig, Timothy (2010). "Social savings." Journal of Economic Surveys 24(5): 775-800.

Lockwood, William (1954). The Economic Development of Japan: Growth and Structural Change 1868-1938. Princeton, New Jersey: Princeton University Press.

Madisson, Angus (2003). The World Economy: Historical Statistics. CD-ROM. Paris, France: Organisation for Economic Co-operation and Development.

Nagao, Hampei (1929). The Railways of Japan: Past and Present. New York, New York: Institute of Pacific Relations.

O'Brien, Patrick (1977). The New Economic History of the Railways. London, United Kingdom: Croom Helm.

Rostow, William (1960). The Stages of Economic Growth: a Non-Communist Manifesto. Cambridge, United Kingdom: Cambridge University Press. 
Tang, John (2011). "Technological leadership and late development: evidence from Meiji Japan, 1868-1912." Economic History Review 64(S1): 99-116.

Tokyo Stock Exchange (2012). Company listing information, accessed 24 March 2012. URL: http://www.tse.or.jp/english/listing/index.html.

Yagura, Shintaro and Yoshiro Ikushima (1986). Shuyo Kigyo no Keifuzu [Genealogical Chart of Japanese Major Companies]. Japanese language text. Tokyo, Japan: Yushodo Publishing. 
Figure 1: Japanese rail network expansion

1877

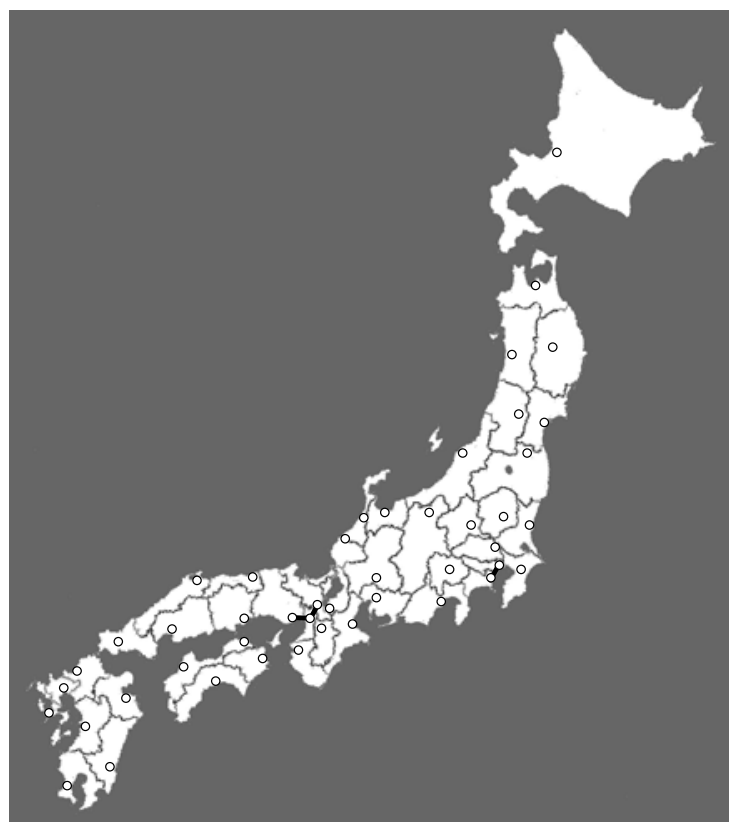

1897

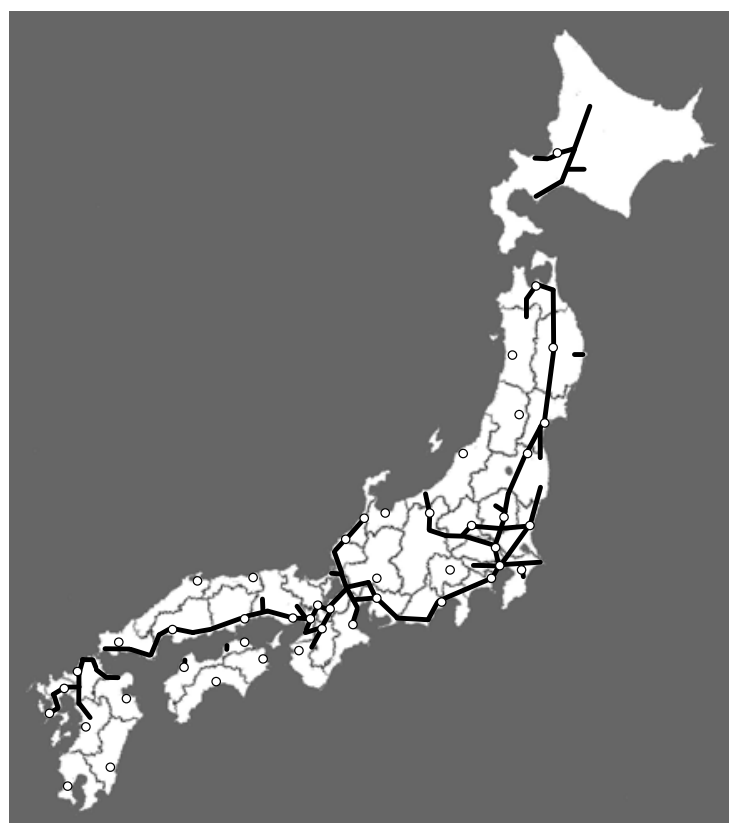

1887

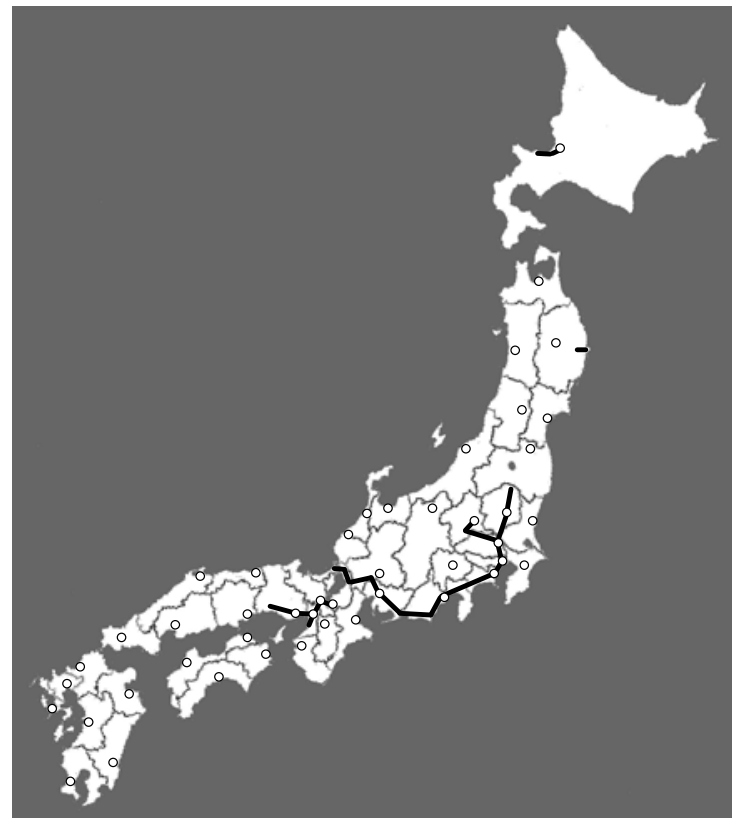

1907

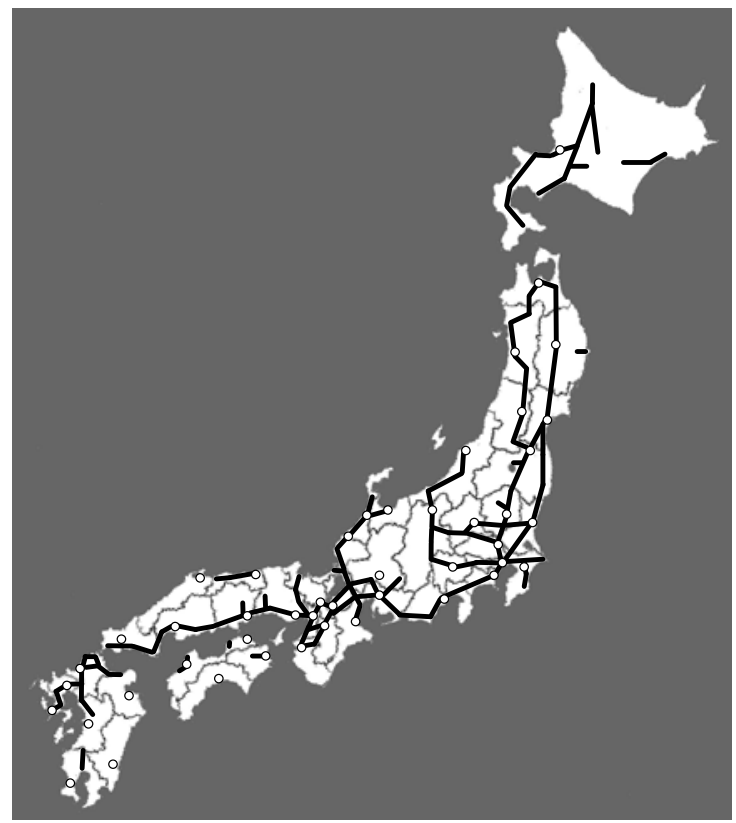

Source: see text. 
Figure 2: Meiji-era trends of economic indicators

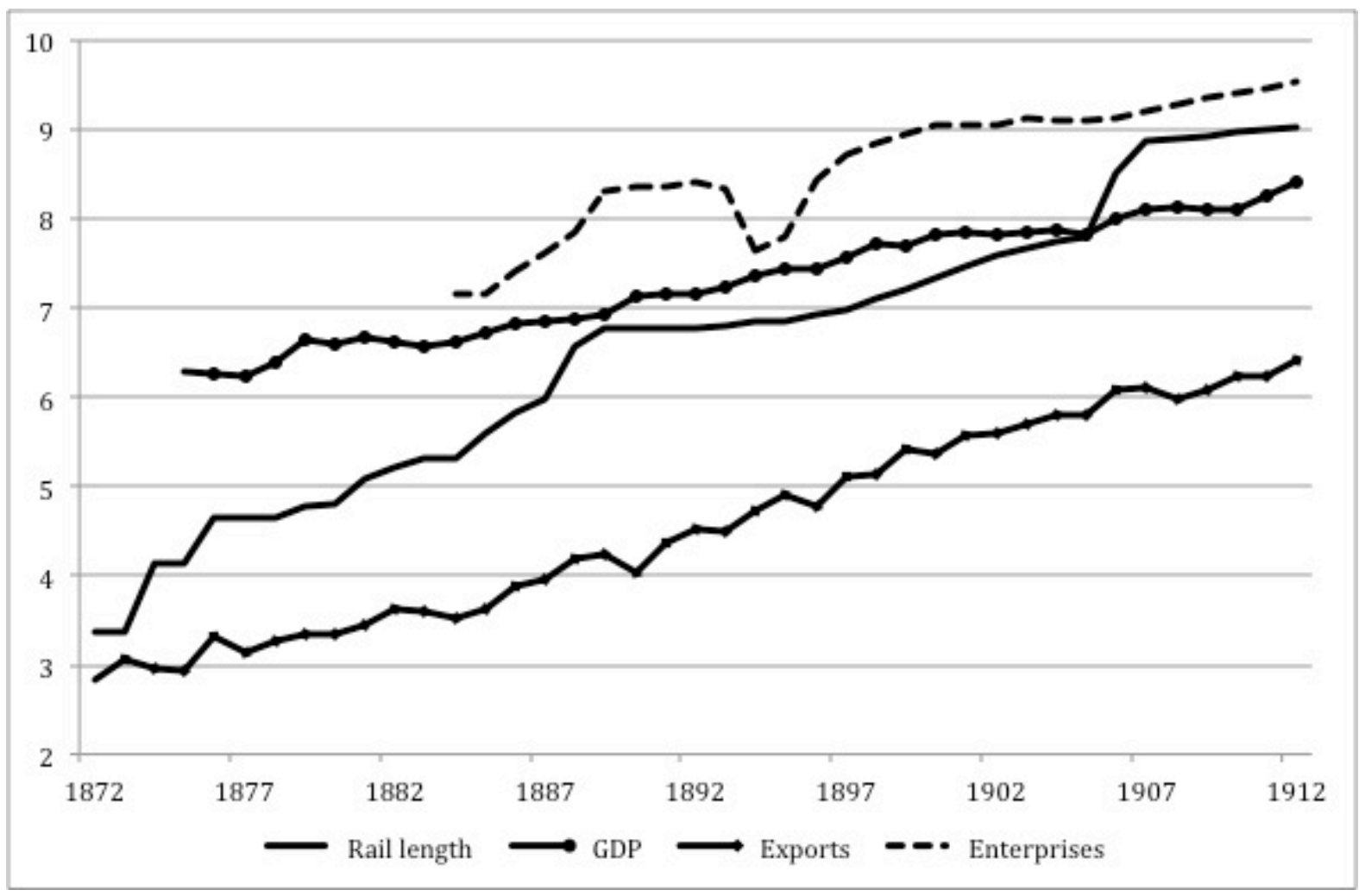

Source: Japan Statistical Association (2007), series 8-4, 10-1, 13-3, and 15-5.

Note: values reported in logs with the following units: rail length (kilometres), GDP and exports (millions of yen, current value), and enterprises (total). 
Figure 3: Bank series comparison, 1893 prefecture share

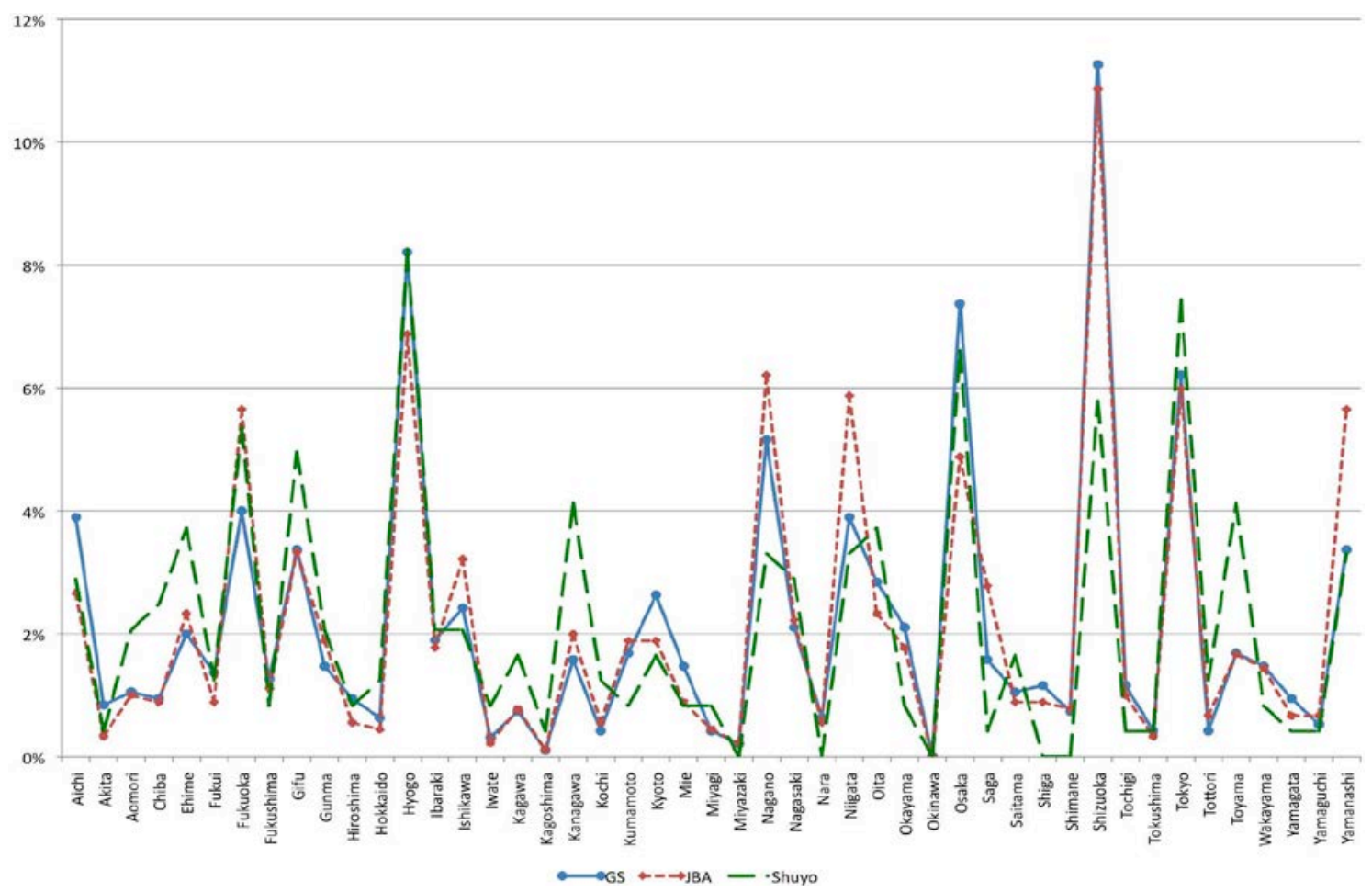

Source: see text

Figure 4: Bank series comparison, 1912 prefecture share

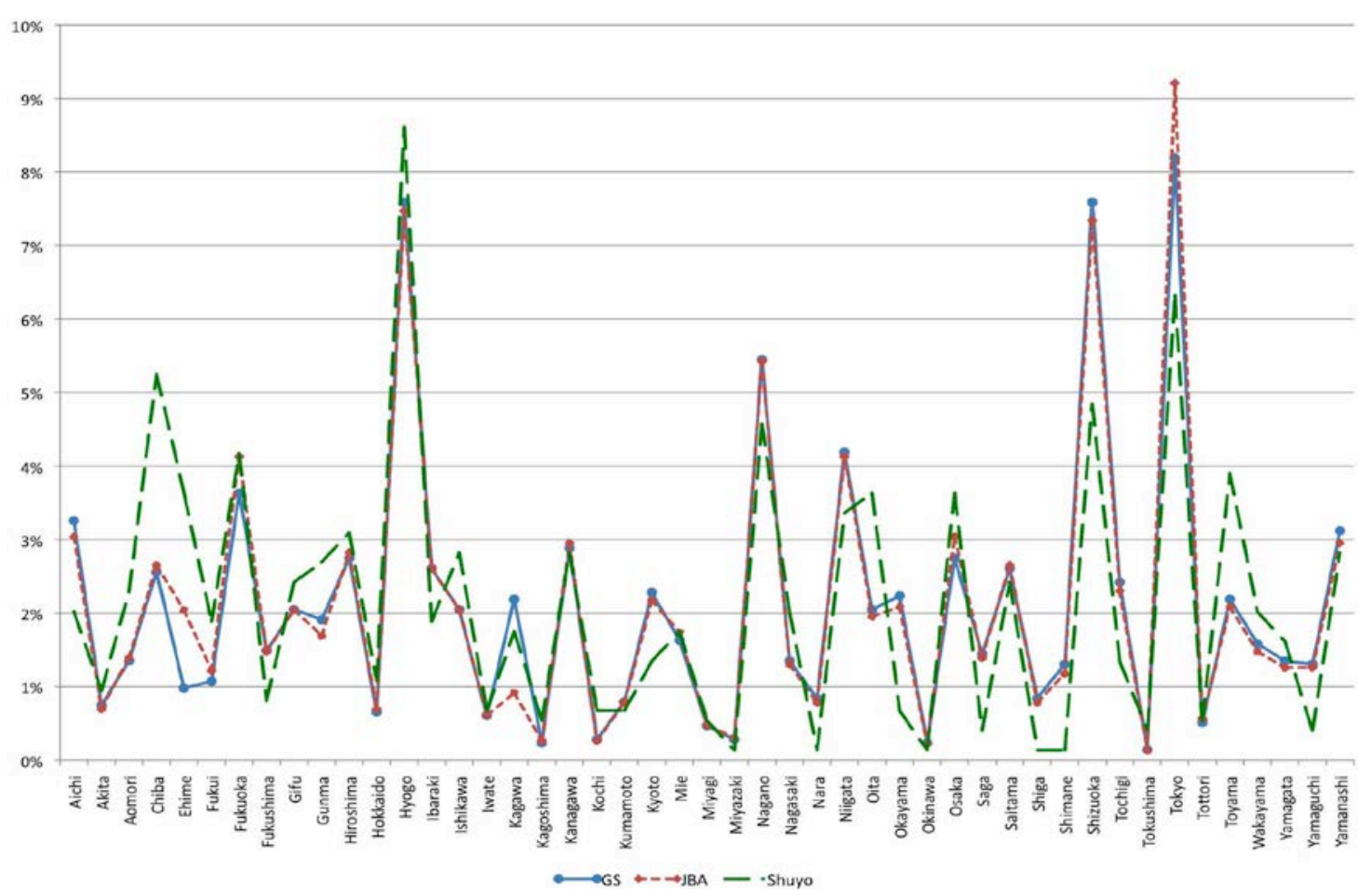

Source: see text 
Figure 5: Difference-in-differences groups

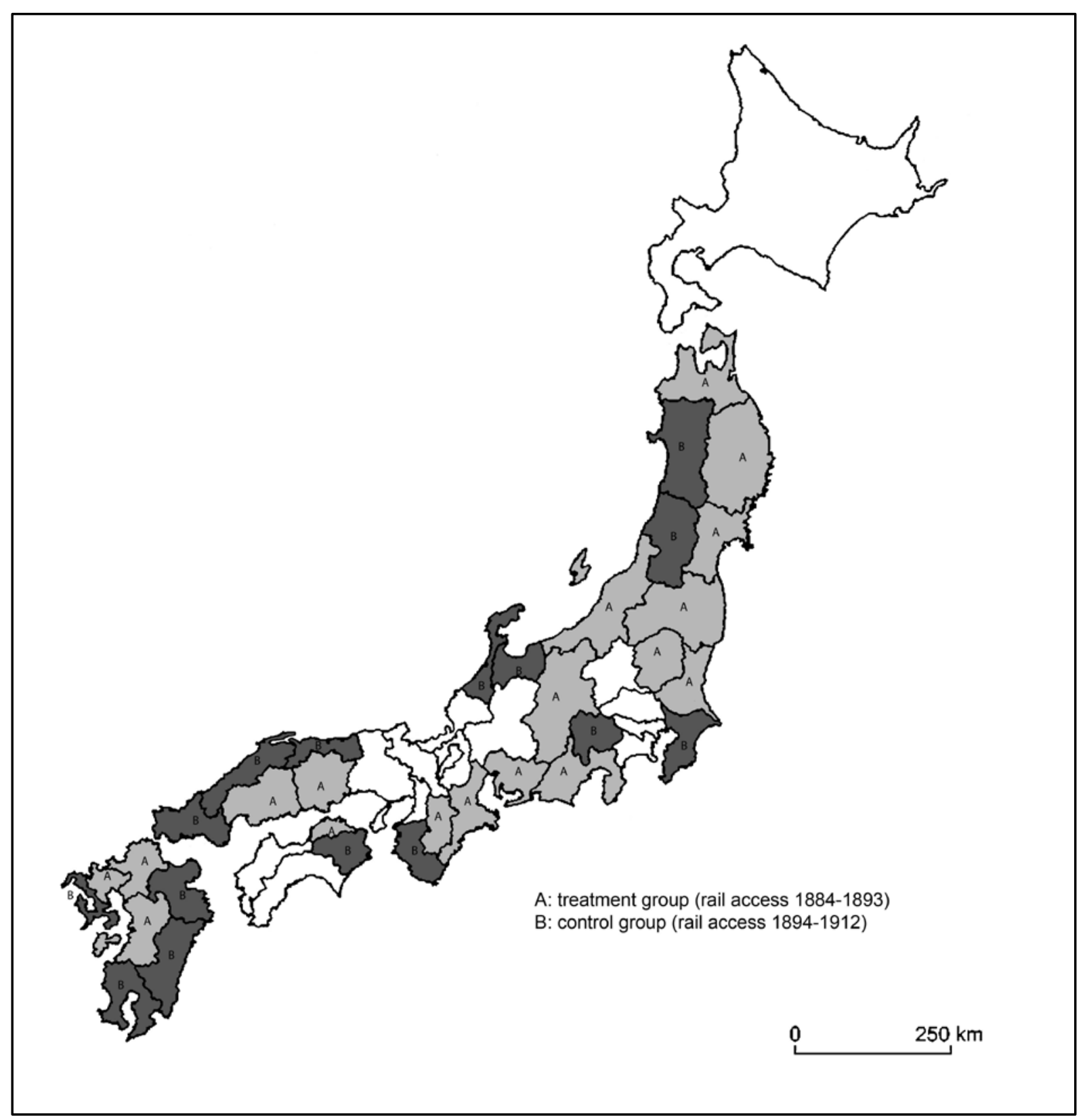

Source: see text. 
Table 1: Length of Japanese rail network, kilometres

\begin{tabular}{llll}
\hline Year & Public & Private $^{\mathrm{a}}$ & Total \\
\hline 1872 & 29 & 0 & 29 \\
1877 & 105 & 0 & 105 \\
1882 & 185 & 0 & 185 \\
1887 & 393 & 472 & 865 \\
1892 & 886 & 2,125 & 3,011 \\
1897 & 1,065 & 3,681 & 4,746 \\
1902 & 1,974 & 5,398 & 7,372 \\
1907 & 7,152 & 1,568 & 8,720 \\
1912 & 8,396 & 2,988 & 11,384 \\
\hline
\end{tabular}

Source: Japan Statistical Association (2007), series 8-4 and 8-14.

a includes long-distance and local rail/tram networks

Table 2: Descriptive statistics

\begin{tabular}{llll}
\hline & Total & Pre-rail access & Post-rail access \\
\hline Number of start-ups & $\mathbf{1 , 6 4 4}$ & $\mathbf{3 3 9}$ & $\mathbf{1 , 3 0 5}$ \\
Primary production & $\mathbf{6 5}$ & $\mathbf{1 4}$ & $\mathbf{5 1}$ \\
Manufacturing & $\mathbf{4 6 2}$ & $\mathbf{6 0}$ & $\mathbf{4 0 2}$ \\
Ceramic, glass & 32 & 5 & 27 \\
Chemicals & 80 & 1 & 79 \\
Food processing & 53 & 11 & 42 \\
Machinery & 70 & 8 & 62 \\
Metal processing & 41 & 3 & 38 \\
Textiles & 142 & 25 & 117 \\
Wood processing & 42 & 7 & 35 \\
Other manufacturing & 2 & 0 & 2 \\
Finance & $\mathbf{8 7 0}$ & $\mathbf{2 5 0}$ & $\mathbf{6 2 0}$ \\
Banking & 757 & 213 & 544 \\
Other finance & 113 & 37 & 76 \\
Services & $\mathbf{2 4 7}$ & $\mathbf{1 5}$ & $\mathbf{2 3 2}$ \\
Retail & 64 & 7 & 57 \\
Transport and utilities & 171 & 6 & 165 \\
Other services & 12 & 2 & 10 \\
\hline
\end{tabular}

Source: see text.

Table 3: Banking series correlations

\begin{tabular}{llll}
\hline & GS series, & JBA series, & JBA series, \\
& $1893-1912$ & $1893-1912$ & $1868-1912$ \\
\hline JBA series, 1893-1912 & 0.993 & 1.000 & \\
& $(940)$ & & \\
Shuyo series, 1893-1912 & 0.828 & 0.831 & \\
& $(940)$ & $(940)$ & 0.875 \\
Shuyo series, 1868-1912 & & & $(2,115)$ \\
\hline
\end{tabular}

Source: see text.

Note: all correlation coefficients are statistically significant at the 1 percent level. Number of observations in parentheses. 


\begin{tabular}{|c|c|c|c|c|}
\hline & $\begin{array}{ll}\begin{array}{l}\text { Rail access } \\
\text { year }\end{array} & \\
\end{array}$ & $\begin{array}{l}\text { Population } \\
\text { (1883) }\end{array}$ & $\begin{array}{l}\text { Coastline } \\
(\mathrm{km})\end{array}$ & $\begin{array}{ll}\begin{array}{l}\text { Surface } \\
\left(\mathrm{km}^{2}\right)\end{array} & \text { area } \\
\end{array}$ \\
\hline Japan & & $37,451,800$ & 33,889 & 381,808 \\
\hline Aichi & 1886 & $1,364,400$ & 548 & 5,055 \\
\hline Akita & 1899 & 639,500 & 304 & 11,724 \\
\hline Aomori & 1891 & 490,600 & 744 & 9,631 \\
\hline Chiba & 1894 & $1,107,500$ & 535 & 5,079 \\
\hline Ehime & 1914 & 868,320 & 1,533 & 5,699 \\
\hline Fukui & 1882 & 580,600 & 397 & 4,018 \\
\hline Fukuoka & 1889 & $1,133,800$ & 589 & 4,940 \\
\hline Fukushima & 1887 & 854,700 & 191 & 13,782 \\
\hline Gifu & 1883 & 869,100 & 0 & 10,462 \\
\hline Gunma & 1883 & 629,600 & 0 & 6,315 \\
\hline Hiroshima & 1891 & $1,256,600$ & 1,113 & 8,437 \\
\hline Hokkaido & 1880 & 227,900 & 4,377 & 88,454 \\
\hline Hyogo & 1874 & $1,442,600$ & 783 & 8,427 \\
\hline Ibaraki & 1885 & 925,400 & 186 & 6,100 \\
\hline Ishikawa & 1897 & 732,600 & 581 & 4,198 \\
\hline Iwate & 1890 & 613,300 & 661 & 15,235 \\
\hline Kagawa & 1889 & 639,980 & 694 & 1,845 \\
\hline Kagoshima & 1900 & 933,800 & 2,722 & 9,081 \\
\hline Kanagawa & 1872 & 650,405 & 400 & 2,352 \\
\hline Kochi & 1924 & 545,200 & 691 & 7,088 \\
\hline Kumamoto & 1891 & $1,000,000$ & 1,068 & 7,438 \\
\hline Kyoto & 1876 & 845,500 & 310 & 4,559 \\
\hline Mie & 1890 & 874,900 & 1,105 & 5,702 \\
\hline Miyagi & 1887 & 643,400 & 846 & 7,287 \\
\hline Miyazaki & 1911 & 381,500 & 445 & 7,738 \\
\hline Nagano & 1888 & $1,040,100$ & 0 & 13,557 \\
\hline Nagasaki & 1897 & 704,500 & 4,137 & 4,116 \\
\hline Nara & 1890 & 469,539 & 0 & 3,730 \\
\hline Niigata & 1886 & $1,583,400$ & 585 & 12,579 \\
\hline Oita & 1897 & 750,100 & 725 & 6,225 \\
\hline Okayama & 1890 & $1,035,000$ & 539 & 7,019 \\
\hline Okinawa & 2003 & 364,400 & 1,652 & 2,387 \\
\hline Osaka & 1874 & $1,163,261$ & 223 & 1,814 \\
\hline Saga & 1889 & 518,600 & 357 & 2,444 \\
\hline Saitama & 1883 & 980,100 & 0 & 3,804 \\
\hline Shiga & 1880 & 634,600 & 0 & 4,051 \\
\hline Shimane & 1908 & 677,500 & 814 & 6,618 \\
\hline Shizuoka & 1888 & 975,900 & 514 & 7,770 \\
\hline Tochigi & 1885 & 623,100 & 0 & 6,448 \\
\hline Tokushima & 1899 & 649,300 & 363 & 4,135 \\
\hline Tokyo & 1872 & $1,325,295$ & 760 & 2,142 \\
\hline Tottori & 1902 & 380,200 & 144 & 3,489 \\
\hline Toyama & 1897 & 700,700 & 117 & 4,257 \\
\hline Wakayama & 1898 & 610,800 & 628 & 4,733 \\
\hline Yamagata & 1901 & 704,500 & 0 & 4,455 \\
\hline Yamaguchi & 1899 & 894,900 & 110 & 9,306 \\
\hline Yamanashi & 1897 & 414,800 & 1,398 & 6,082 \\
\hline
\end{tabular}

Source: see text. 
Table 5: Difference-in-differences results, all industries

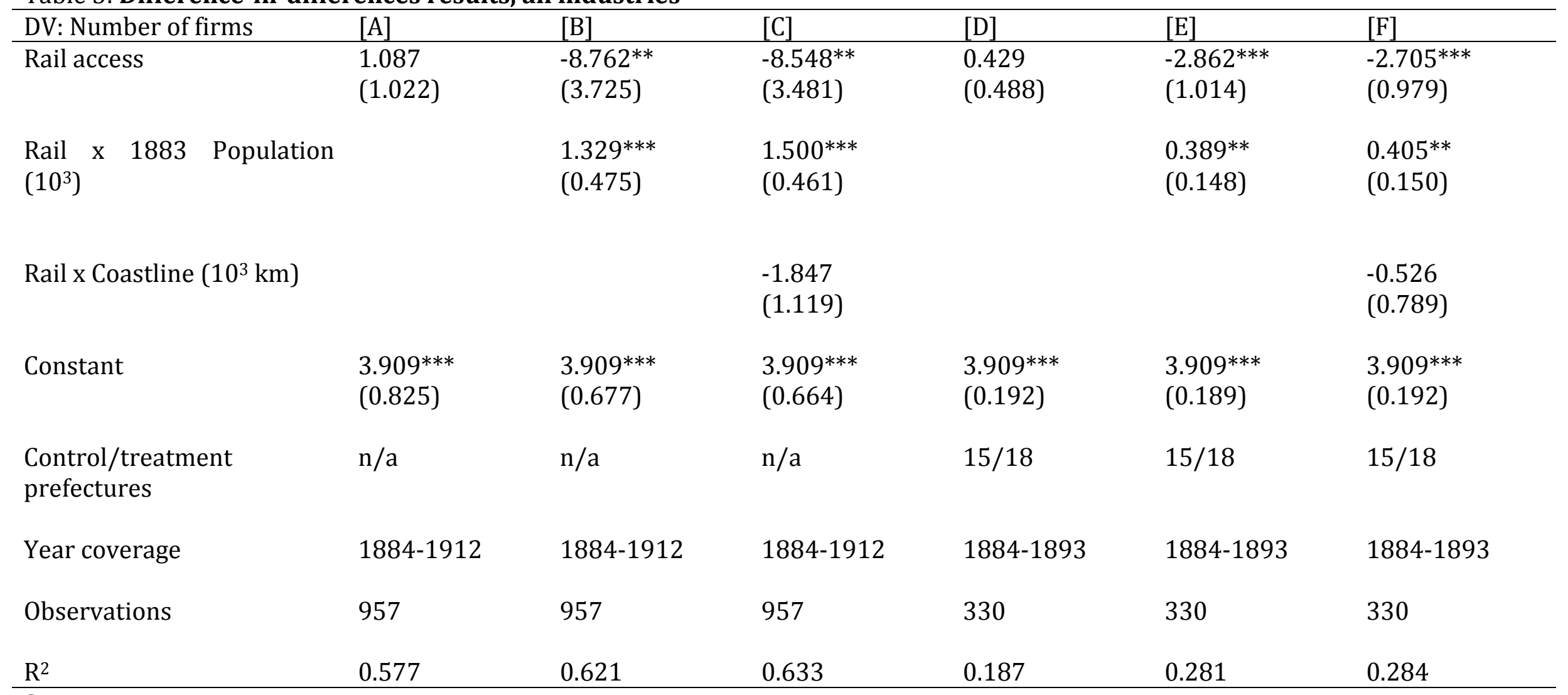

Source: see text.

Significance levels: ${ }^{*} 10 \%, * * 5 \%,{ }^{* * *} 1 \%$

Note: all specifications include prefecture and year fixed effects. Robust standard errors are clustered by prefecture. 
Table 6: Difference-in-differences results, major industry groups

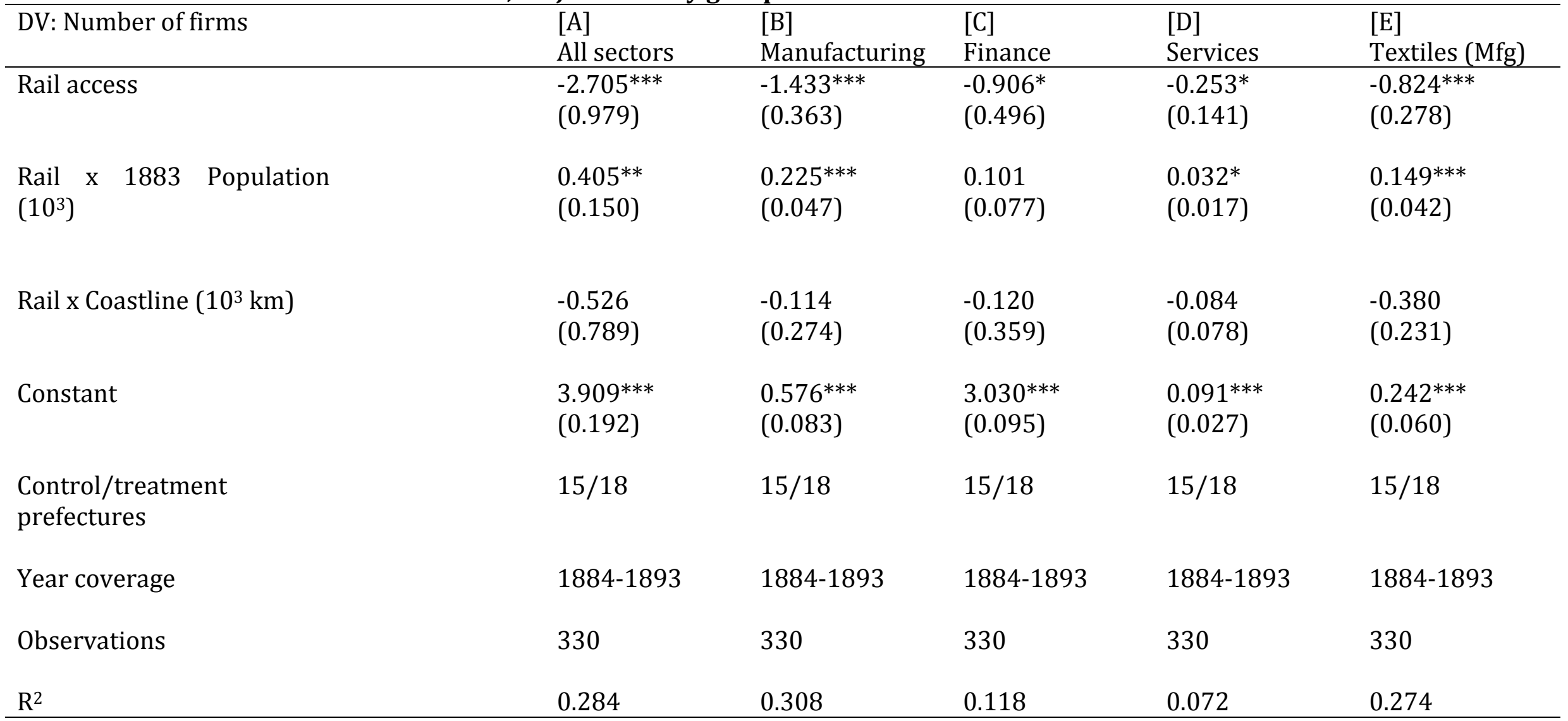

Source: see text.

Significance levels: $* 10 \%$, $* * 5 \%$, ${ }^{* * *} 1 \%$

Note: all specifications include prefecture and year fixed effects. Robust standard errors are clustered by prefecture. 
Table 7: Difference-in-differences results, net firm growth

\begin{tabular}{|c|c|c|c|c|c|}
\hline $\begin{array}{l}\text { DV: Change to number of } \\
\text { firms }\end{array}$ & $\begin{array}{l}{[\mathrm{A}]} \\
\text { All sectors }\end{array}$ & $\begin{array}{l}{[\mathrm{B}]} \\
\text { Manufacturing }\end{array}$ & $\begin{array}{l}{[\mathrm{C}]} \\
\text { Finance }\end{array}$ & $\begin{array}{l}{[\mathrm{D}]} \\
\text { Services }\end{array}$ & $\begin{array}{l}{[\mathrm{E}]} \\
\text { Textiles (Mfg) }\end{array}$ \\
\hline $\begin{array}{l}\text { Rail x } 1883 \text { Population } \\
\left(10^{3}\right)\end{array}$ & $\begin{array}{l}0.064 \\
(0.062)\end{array}$ & $\begin{array}{l}0.046 \\
(0.046)\end{array}$ & $\begin{array}{l}-0.002 \\
(0.039)\end{array}$ & $\begin{array}{l}0.011^{*} \\
(0.006)\end{array}$ & $\begin{array}{l}0.043^{* *} \\
(0.019)\end{array}$ \\
\hline Constant & $\begin{array}{l}0.271 \\
(0.309)\end{array}$ & $\begin{array}{l}0.062 \\
(0.100)\end{array}$ & $\begin{array}{l}0.262 \\
(0.181)\end{array}$ & $\begin{array}{l}0.031 \\
(0.034)\end{array}$ & $\begin{array}{l}0.034 \\
(0.068)\end{array}$ \\
\hline $\begin{array}{l}\text { Control/treatment } \\
\text { prefectures }\end{array}$ & $15 / 18$ & $15 / 18$ & $15 / 18$ & $15 / 18$ & $15 / 18$ \\
\hline Observations & 330 & 330 & 330 & 330 & 330 \\
\hline $\mathrm{R}^{2}$ & 0.046 & 0.034 & 0.048 & 0.030 & 0.086 \\
\hline
\end{tabular}

Source: see text.

Significance levels: *10\%, **5\%, ***1\%

Note: all specifications include prefecture and year fixed effects. Robust standard errors are clustered by prefecture. 
Table 8: Difference-in-differences robustness check, JBA correlation

\begin{tabular}{|c|c|c|c|c|c|}
\hline \multirow[t]{2}{*}{ DV: Number of firms } & {$[\mathrm{A}]$} & [B] & {$[\mathrm{C}]$} & [D] & {$[\mathrm{E}]$} \\
\hline & All sectors & Manufacturing & Finance & Services & Textiles (Mfg) \\
\hline $\begin{array}{l}\text { Rail x } 1883 \text { Population } \\
\left(10^{3}\right)\end{array}$ & $\begin{array}{l}0.413^{* *} \\
(0.153)\end{array}$ & $\begin{array}{l}0.230^{* * *} \\
(0.047)\end{array}$ & $\begin{array}{l}0.102 \\
(0.078)\end{array}$ & $\begin{array}{l}0.033^{*} \\
(0.017)\end{array}$ & $\begin{array}{l}0.150^{* * *} \\
(0.043)\end{array}$ \\
\hline Constant & $\begin{array}{l}4.276^{* * *} \\
(0.217)\end{array}$ & $\begin{array}{l}0.655^{* * *} \\
(0.095)\end{array}$ & $\begin{array}{l}3.276^{* * *} \\
(0.108)\end{array}$ & $\begin{array}{l}0.103^{* * *} \\
(0.031)\end{array}$ & $\begin{array}{l}0.276^{* * *} \\
(0.068)\end{array}$ \\
\hline $\begin{array}{l}\text { Control/treatment } \\
\text { prefectures }\end{array}$ & $12 / 17$ & $12 / 17$ & $12 / 17$ & $12 / 17$ & $12 / 17$ \\
\hline Observations & 290 & 290 & 290 & 290 & 290 \\
\hline $\mathrm{R}^{2}$ & 0.301 & 0.320 & 0.129 & 0.081 & 0.278 \\
\hline
\end{tabular}

Source: see text.

Significance levels: $* 10 \%, * * 5 \%, * * * 1 \%$

Note: all specifications include prefecture and year fixed effects. Robust standard errors are clustered by prefecture. Prefectures from the control and treatment groups are limited to those with correlation coefficients exceeding 0.90 based on the Japanese Bankers Association series. 
Table 9: Difference-in-differences robustness check, coastline restriction

\begin{tabular}{|c|c|c|c|c|c|}
\hline DV: Number of firms & {$[\mathrm{A}]$} & [B] & {$[\mathrm{C}]$} & [D] & {$[\mathrm{E}]$} \\
\hline $\begin{array}{l}\text { Rail x } 1883 \text { Population } \\
\left(10^{3}\right)\end{array}$ & $\begin{array}{l}0.626^{* *} \\
(0.251)\end{array}$ & $\begin{array}{l}0.285^{* * *} \\
(0.074)\end{array}$ & $\begin{array}{l}0.178 \\
(0.129)\end{array}$ & $\begin{array}{l}0.053^{* * *} \\
(0.018)\end{array}$ & $\begin{array}{l}0.191^{* * *} \\
(0.068)\end{array}$ \\
\hline Constant & $\begin{array}{l}3.913^{* * *} \\
(0.244)\end{array}$ & $\begin{array}{l}0.391^{* * *} \\
(0.100)\end{array}$ & $\begin{array}{l}3.174^{* * *} \\
(0.126)\end{array}$ & $\begin{array}{l}0.043 \\
(0.024)\end{array}$ & $\begin{array}{l}0.130^{*} \\
(0.067)\end{array}$ \\
\hline $\begin{array}{l}\text { Control/treatment } \\
\text { prefectures }\end{array}$ & $11 / 12$ & $11 / 12$ & $11 / 12$ & $11 / 12$ & $11 / 12$ \\
\hline $\mathrm{R}^{2}$ & 0.394 & 0.388 & 0.164 & 0.174 & 0.374 \\
\hline
\end{tabular}

Source: see text.

Significance levels: $* 10 \%, * * 5 \%, * * * 1 \%$

Note: all specifications include prefecture and year fixed effects. Robust standard errors are clustered by prefecture. Prefectures from the control and treatment groups are limited to those with coastlines between 1 and 1,000 kilometres in length. 
Table 10: Difference-in-differences robustness check, surface area restriction

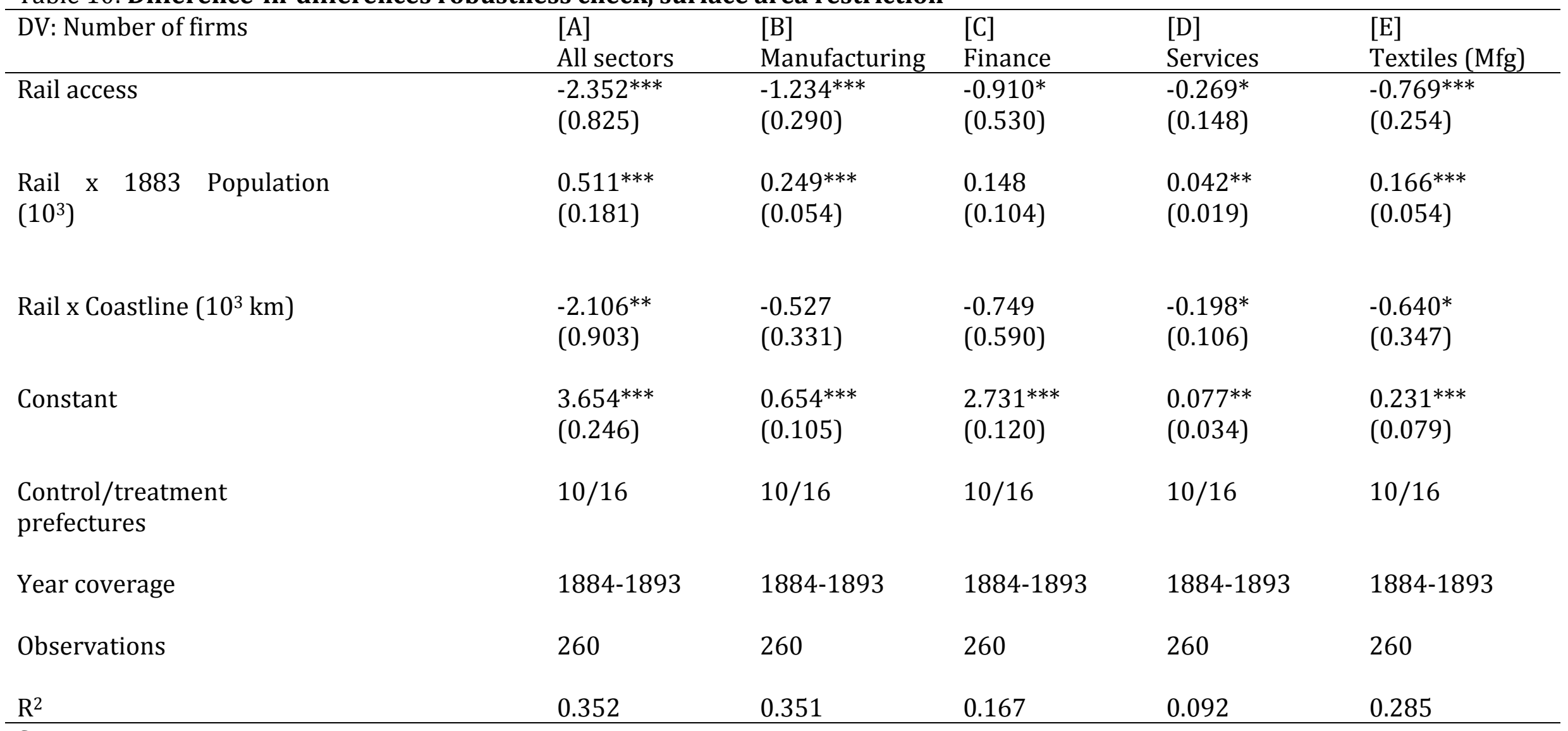

Source: see text.

Significance levels: *10\%, **5\%, $* * * 1 \%$

Note: all specifications include prefecture and year fixed effects. Robust standard errors are clustered by prefecture. Prefectures from the control and treatment groups are limited to those with surface areas within one standard deviation of the prefectural average. 